\title{
A betakarítási idő hatása a moldvai sárkányfü (Dracocephalum moldavica L.) droghozamára és minőségére
}

\section{Gosztola Beáta* ${ }^{*}$ Balogh Dóra, Ruttner Klára}

Szent István Egyetem, Kertészettudományi Kar, Gyógy- és Aromanövények Tanszék, 1118 Budapest, Villányi út 29-43.

\footnotetext{
*e-mail: gosztola.beata@kertk.szie.hu
}

A moldvai sárkányfű régóta ismert és kedvelt egyéves gyógy- és füszernövényünk. Virágzó állapotban gyűjtött és megszárított föld feletti hajtása és illóolaja étvágyjavító, emésztést serkentő, szélhajtó, görcsoldó és nyugtató hatású, de kísérleti eredmények alapján antiszeptikus, antibakteriális és számottevő antioxidáns tulajdonságokkal is rendelkezik. A kínai gyógyászatban szív- és érrendszeri betegségek ellen alkalmazzák. Az élelmiszeriparban édes borok, ürmösök, üdítők, saláták ízesítője, de ízjavítóként teakeverékekbe is teszik.

Kísérletünkben a betakarítási idő droghozamra (morzsolt drogtömeg) és annak minőségére (illóolaj-tartalom és -összetétel, összfenol-tartalom, antioxidánskapacitás) gyakorolt hatását vizsgáltuk 8 eltérő származású moldvai sárkányfü taxon esetén. Az állományokat 2017-ben Soroksáron létesítettük azonos környezeti körülmények között, ahol a mintavételezésre 5 alkalommal: virágzás előtt, virágzás kezdetén, teljes virágzásban, elvirágzáskor és magérés stádiumában került sor.

A morzsolt drogtömeg virágzás előtt volt a legalacsonyabb minden taxon esetén (5,1-7,3 g/egyed), a legmagasabb pedig teljes virágzásban ill. elvirágzáskor (11,3-23,3 g/egyed), de a populációk között is mutatkoztak szignifikáns különbségek. Az illóolaj-tartalom a virágzás folyamán növekvő tendenciát mutatott, a taxonok többségénél teljes virágzáskor érte el maximumát $(0,56-1,04 \mathrm{ml} / 100 \mathrm{~g})$, majd elnyíláskor jelentősen lecsökkent mennyisége. A legalacsonyabb illóolaj-tartalmat magéréskor mértük mindegyik állományban $(0,05-0,29 \mathrm{ml} / 100 \mathrm{~g})$. A populációk között ez esetben is szignifikáns különbségeket tapasztaltunk, betakarítási időtől függetlenül. Illóolaj-összetétel szempontjából az eltérő származású állományok között nem találtunk jelentős különbségeket. Minden taxon mintájában a geranil-acetát, citrál-a és citrál-b voltak a fő illóolaj összetevők. A geranil-acetát illóolajon belüli részaránya a virágzás folyamán nőtt, a legmagasabb értékeket magéréskor mértük (44,7-53\%), míg a citrál koponensek felhalmozása csökkent a virágzás során.

A vizes és alkoholos kivonatok összfenol-tartalmát és összantioxidáns kapacitását összehasonlítva megállapítottuk, hogy a vizes kivonatok minden esetben szignifikánsan magasabb hatóanyag-tartalommal rendelkeztek. Az összfenol-tartalom 
teljes virágzáskor volt a legmagasabb $(226,5-649,2 \mathrm{mg} / \mathrm{g})$, a legalacsonyabb pedig magéréskor (76,9-139,9 mg/g), és antioxidáns-kapacitás esetén is hasonló tendenciát tapasztaltunk. Teljes virágzás ill. elvirágzás során mértük a legmagasabb antioxidánsaktivitást (150,7-276,6 mg/g), mely magéréskor lecsökkent 93,0-151,4 mg/g-ra. 